Pókecz Kovács Attila

\title{
A MAGYAR KBTK. A 19. SZÁZADI EURÓPAI BÜNTETÖJOGI KODIFIKÁCIÓK FÉNYÉBEN
}

\section{The Hungarian Criminal Code of Infringements in the Light of $19^{\text {th }}$ Century European Criminal Codifications}

Prof. Dr. Pókecz Kovács Attila, egyetemi tanár, Nemzeti Közszolgálati Egyetem Államtudományi és Nemzetközi Tanulmányok Kar Állam- és Jogtörténeti Tanszék, pokecz.kovacs.attila@uni-nke.hu

Jelen tanulmány az NKE ÁNTK szervezésében 2019. november 29-én „A kihágásokról szóló büntetötörvénykönyv az 1879. évi XL. törvénycikk elfogadásának 140. évfordulója alkalmából” címmel megrendezett konferencián elhangzott referátum átdolgozott, szerkesztett változata. A tanulmány az összehasonlító jogtörténeti módszerrel vizsgálja a Csemegi Károly által szerkesztett magyar kihágási törvénykönyv európai modelljeit. Vizsgálatai során az 1810-es francia Code Pénal, az 1867-es belga Büntetö törvénykönyv és az 1871. évi német Btk. kihágásokat tartalmazó részeinek elemzésére és a magyar szabályozással való összevetésre fókuszál. A szerző megállapítja, hogy a magyar Kbtk. ugyan figyelembe vette az európai mintákat, de egyiket sem követte szolgai módon. A kihágások anyagi jogát európai színvonalon szabályozta ugyan, de az eljárások hatékony lefolytatásához szükséges szervezeti változtatások nem történtek meg, így nem jött létre a francia és a belga mintának megfelelöen müködő egységes és általános kihágási bíróság, ezáltal az eljárások anyagi és személyi feltételei sem lettek kielégítöen biztosítva.

\section{KulcsszavaK:}

belga büntető törvénykönyv (1867), Csemegi Károly, francia Code Pénal, kihágások, kihágási bíróságok, magyar Kbtk., német büntető törvénykönyv (1871)

The present study is a revised and edited version of the paper presented at the conference organised by the University of Public Service Faculty of Public Governance and International Studies on 29 November 2019, entitled 'Criminal Code of Infringements on the occasion of the $140^{\text {th }}$ anniversary of the adoption of Article XL of the Act of 1879'. The study examines the European models of the Hungarian infringement code edited by Károly Csemegi using the comparative legal history method. In his investigations of the French Code Pénal of 1810, the Belgian Penal Code of 
1867, and the German Criminal Code of 1871 he focuses on the analysis of the parts containing infringements and the comparison with the Hungarian regulations. The author states that the Hungarian Kbtk., although it took European patterns into account, did not follow any of them in a slavish manner. Although the substantive law of the infringements was regulated at European level, the organisational changes necessary for the effective conduct of the proceedings were not made, so that a uniform and general infringement court modeled on the French and Belgian models was not created, neither were the material and personal conditions.

\section{KeYWORDS:}

Belgian Penal Code (1867), Károly Csemegi, French Code Pénal, infringements, infringement courts, Hungarian Kbtk., German Criminal Code (1871) 


\section{BEVEZETÉS}

A 19. századi kodifikációk történetének valamennyi jogtudományi terület vonatkozásában elengedhetetlen elemét képezi az európai minták tanulmányozása. ${ }^{1}$ Ez a megállapítás fokozottan érvényes a Csemegi-kódexre és a magyar Kbtk.-ra, mivel mindkét törvény a 19. századi modernizációs törekvések azon időszakában született, amikor a magyar jogalkotók körében a legnagyobb nyitottság mutatkozott a recepcióra. ${ }^{2}$ Mindkét törvény javaslatának megfogalmazása egyetlen személyhez, Csemegi Károly nevéhez füződik. A bűntett és a vétség kategóriákat a Csemegi-kódexben, az enyhébb súlyú cselekményeket (a kihágásokat) pedig egy különálló törvényben - az 1879. évi XL. törvénycikkben (Kbtk.) - szabályozták. Az 1879. évi XL. tc. 1. \$-a szerint kihágást képez azon cselekmény, amelyet: 1. a törvény, 2. miniszteri rendelet, 3. a törvényhatóság, vagy 4. törvényhatósági joggal fel nem ruházott szabad királyi város, vagy rendezett tanáccsal bíró város által kiadott szabályrendelet kihágásnak nyilvánít. ${ }^{3}$

Csemegi Károly (1826-1899) - a Kbtk. kodifikátora - több idegen nyelvet beszélő, művelt jogász volt. ${ }^{4}$ Anyja csak németül beszélt vele, apja kiválóan értett franciául, mivel korábban Párizsban dolgozott banki alkalmazottként. A gimnázium elvégzésekor latin, görög, német, francia és olasz nyelvismerettel rendelkezett. Kedvenc olvasmányai az 1843. évi büntetöjogi javaslat és a napóleoni büntető törvénykönyv, a Code Pénal voltak. ${ }^{5}$ Az 1849-1850. évi aradi és temesvári várfogsága idején megtanult angolul is. Széles körű műveltségével és az öt idegen nyelvre kiterjedő nyelvismeretével már kortársai elismerését is kivívta. ${ }^{6}$

Fayer László (1842-1906), a 19. század neves büntetőjogásza az 1895-ben Budapesten megjelent $A$ büntetőjog kézikönyve I. címü müvében a Csemegi-kódex kapcsán írta a következőket, amely megállapításai a Kbtk.-ra is igazak: „[M]elyik külföldi törvénykönyvre támaszkodott Csemegi? Munkája eklektikus jellegű. Először is használta az osztrák 1870-iki bizottsági javaslatot (Ausschuss-Entwurf), melyet a kormányjavaslat átdolgozásával az osztrák birodalmi tanács bizottsága készített. Másod sorban használta a német büntetö-törvénykönyvet, és pedig leginkább technikai kérdések tekintetében, harmad sorban a franczia-belgát, negyed sorban az olasz javaslatokat. Es egyáltalán az európai szakirodalmat."7

Bruno Oppetit: Essai sur la codification. Paris, PUF, 1998. 57-66.

Kajtár, István: Strafrechtsrezeption in Ungarn in dem 19. Jahrhundert. In Mezey, Barna (szerk.): Strafrechtsgeschichte an der Grenze des nächtsten Jahrtausendes. Budapest, Gondolat, 2003. 27-53.

1879. évi XL. törvénycikk a magyar büntető törvénykönyv a kihágásokról, 1. \$.

4 Sebestyén István: Csemegi Károly. In Hamza Gábor - Siklósi Iván (szerk.): Magyar jogtudósok 3. Budapest, Nemzeti Tankönyvkiadó, 2006. 43-44.

5 Mezey, Barna: Strafrechtskodifikation in Ungarn im Jahre 1878. In Mezey, Barna (szerk.): Strafrechtsgeschichte an der Grenze des nächtsten Jahrtausendes. Budapest, Gondolat, 2003. 161-163.

6 Mezey Barna: Egy jogászkarrier a 19. században. Csemegi Károly (1826-1899). In A praxistól a kodifikációig. Csemegi Károly emlékére, 1826-1899. Budapest, Osiris, 2001. 9-23. 21.

Fayer László: A büntetőjog kézikönyve I. Budapest, Franklin Társulat, 1895. 53. 
A Csemegi által elkészített törvénytervezet alapjául szolgáló európai modellek között a kortárs büntetőjogász jogtudós véleménye alapján tehát az osztrák, a német, a francia, a belga és az olasz törvényeket kell figyelembe venni. Rövid tanulmányomban - mivel ennek a kérdésnek a vizsgálata önálló tanulmány tárgya is - nem vállalkozom az osztrák hatások vizsgálatára. ${ }^{8} \mathrm{Az}$ olasz büntető törvénykönyvet a magyar Kbtk. hatálybalépése után fogadták el, és 1890-ben Codice Zanardelli néven lépett hatályba. ${ }^{9}$ Bár a beterjesztő igazságügy-miniszter nevét viselő olasz kódex a 19. század egyik legjobban sikerült büntető törvénykönyve, ${ }^{10}$ a Kbtk. elkészülte előtt megjelent tervezetek későbbi változásai miatt (az elfogadásáig 12 tervezet készült) ${ }^{11}$ tudományos szempontból jelentős hatás kimutatására nem alkalmasak.

Vizsgálataimat a terjedelmi korlátokra, valamint fentiekben kifejtett megszorításokra tekintettel ezért az 1810-es francia Code Pénal (Code des délits et des peines), az 1867-es belga Büntető törvénykönyv (Code Pénal) és az 1871. évi német Btk. (Reichsstrafgesetzbuch) kihágásokat tartalmazó részeinek elemzésére fókuszálva kívánom elvégezni.

\section{A FRANCIA KIHÁGÁSI JOG 19. SZÁZADI SZABÁLYOZÁSA}

Az 1810-es francia büntető törvénykönyv (Code Pénal) a 19. század első jelentős és egyben a legnagyobb hatású büntető törvénykönyve. Fayer László álláspontja szerint a napóleoni Code Pénal európai anyakódexnek számít, nemzetközi hatásában ez azt jelenti, hogy több kódexnek az anyja, míg többeknek a nagyanyja. ${ }^{12}$ Keletkezését tekintve a francia büntetöjogi kódex létrejötte illeszkedett a jelentősebb napóleoni kódexek megalkotásának folyamatába. Fontos történeti adalék, hogy az anyagi büntetőjogot tartalmazó kódex két évvel az eljárásjogi törvénykönyv (Code d’instruction criminelle, 1808) után készült el, aminek az az indoka, hogy pragmatikus okokból Napóleon a reformokat a bírósági szervezetrendszer átalakításával kívánta kezdeni. ${ }^{13}$ Mindkét törvénykönyv - az anyagi és az eljárási jogot szabályozó is - 1810. január 1-jén lépett hatályba. ${ }^{14}$ A Code Pénal összeállítására öttagú bizottságot (Treilhard, Blondel, Veillard, Target és Oudart) állított fel a császár, amelynek

\footnotetext{
Az osztrák hatásokat dolgozza fel e lapszámban megjelenő tanulmányában Szabó Mátyás.

Hajdú Lajos: Az államszervezet és jog fejlődése Itáliában. In Horváth Pál (szerk.): Általános jogtörténet. Budapest, Tankönyvkiadó, 1991. 465-466.

10 Rigó Balázs: A büntetőjog történetéből II. Kora újkor - újkor. In Földi András (szerk.): Összehasonlító jogtörténet. Budapest, ELTE Eötvös, 2016. 351-352.

11 Luigi Lacchè: Un code pénal pour l'Unité italienne, le code Zanardelli (1889): la genèse, le débat, le projet juridique. In Le pénal dans tous ses États: Justice, États et sociétés en Europe (XII-XXe siècles). Bruxelles, Presses de l'Université Saint-Louis, 1997. 306-319.

12 Fayer (1895) i. m. 16.

13 Gabriel Lepointe: Histoire des institutions du droit public français au XIXe siècle (1789-1914). Paris, Montchrestien, 1992. 415-421.

14 Romuald Szramkiewicz - Jacques Bouineau: Histoire des institutions 1750-1914. Droit et société en France de la fin de l'Ancien régime à la Première Guerre mondiale. Paris, Litec, 1989. 336.
} 
tagjai között a kor neves büntetőjogászai Treilhard ${ }^{15}$ és Target ${ }^{16}$ személyében képviselve voltak. A csaknem 500 szakaszból (articles) álló francia büntető törvénykönyv 4 fejezete közül az utolsó tárgyalja a kihágásokat („Des contraventions”). A büncselekmények felosztásánál a francia kódex a trichotóm rendszert követte, amelynek alapján megkülönböztették a bűntett (crime), a vétség (délit) és kihágás (contravention) alakzatait. A törvénykönyv szabályozási filozófiáját tekintve átmenetet képez a francia forradalom előtti (ancien régime) és forradalmi jogfelfogás között (révolutionnaire). ${ }^{17}$ A hármas felosztás a forradalom hatása, a büntetések alkalmazásának rugalmas módja és az enyhítő körülmények figyelembevétele pedig az ancien régime hatásait mutatja. ${ }^{18}$

Kiemelném annak jelentőségét, hogy a napóleoni törvénykönyv a hármas felosztást a bírósági hatáskörök tekintetében is következetesen végigvitte. Ennek megfelelően az egyes büncselekménytípusok saját bírói fórumot kaptak. Így a büntettek a Cour d'assis (Esküdtszék), a vétségek a Cour correctionnel (Vétségi bűntetőbíróság), a kihágások pedig a Tribunal de Police (Rendőri kihágási bíróság) hatáskörébe tartoztak. Ezzel a megoldással áttekinthető büntetőbírósági rendszer jött létre, amely a tárgyi és személyi feltételek biztosítása révén hatékonyan alkalmazta az anyagi jogi rendelkezéseket.

Bár a francia megoldás a büncselekményeket tárgyaló bíróságokat három részre osztotta, ennek ellenére a három alakzat egy törvénykönyvben nyert szabályozást. A francia törvény a kihágásokat súlyuk szerint három osztályba sorolta (art. 464-484).

Az 1. osztályba tartozó kihágások az 1-5 frank pénzbüntetéssel, vagy legfeljebb 3 napi elzárással büntethető cselekmények voltak. Pénzbüntetéssel voltak szankcionálhatók például a tűzrendvédelmi szabályokba ütköző, utak tisztításának, karbantartásának elmulasztásával kapcsolatos, a közterületek kivilágításának elmaradása miatti cselekmények. Legfeljebb 3 napi elzárással voltak sújthatók például a tiltott tűzijáték és a termésben okozott károk miatti kihágások.

A 2. osztályba tartoztak a 6-10 frank pénzbüntetéssel vagy 3-5 napi elzárással büntethető cselekmények. E körben pénzbüntetést lehetett például alkalmazni vendéglősök, fogadósok bejelentési nyilvántartási kötelezettségének elmulasztása, épületek elhanyagolása, állatok elhagyása esetén; 3 nap elzárással lehetett szankcionálni az állatokkal vontatott jármüvel való károkozást, amely 5 nap elzárásra volt növelhető visszaeső elkövetőknél.

A 3. osztályban 11-15 frank büntetés vagy 5 nap elzárás volt alkalmazható. Ebben a kategóriában pénzbüntetést lehetett kiszabni például mások állatainak megsebesítése, megölése, óvatlan fegyverhasználattal okozott károk esetén, illetve 5 nap elzárást éjszakai csendháborítás, súlyok, mértékek hamisítása esetében.

15 Pierre Lenoël: Treilhard Jean-Baptiste. In Patrick Arabeyre - Jean-Louis Halpérin - Jacques Krynen (sous la direction): Dictionnaire historique des juristes français XIIe - XXe siècle. Paris, PUF, 2007. 977-978.

16 André Cabanis: Target Guy-Jean-Baptiste. In Patrick Arabeyre - Jean-Louis Halpérin - Jacques Krynen (sous la direction): Dictionnaire historique des juristes français XIIe - XXe siècle. Paris, PUF, 2007. 955-956.

17 Szramkiewicz-Bouineau (1989) i. m. 337.

18 André Laingui - Arlette Lebigre: Histoire du droit pénal I. Paris, Cujas, 1979. 135-136.; Jean-Marie Carbasse: Introduction historique au droit pénal. Paris, PUF, 1990. 315-329. 
A fenti példák alapján látható, hogy a kihágásokat szankcionáló büntetések a pénzbírság, az elzárás és kivételes esetekben a lefoglalás voltak. A pénzbüntetés nem haladhatta meg a 15 frankot, az elzárás az 5 napot. A legrövidebb idejű elzárás időtartama 24 óra volt, a legtöbb 14 nap. Az érintett kérelmére a szabadságvesztés jellegü kihágási büntetéseket - ha nem visszaesőről volt szó - ugyanolyan hosszúságú, a község érdekében való közmunkára (travail au profit de la commune) változtathatták. A pénzbírságot annak a településnek a javára kellett befizetni, ahol a kihágás történt. ${ }^{19}$

A francia törvénykönyv 19. századi hatását jól érzékelteti, hogy bár a magyar jogászok az osztrák, illetve a német eszmékhez állnak közelebb, erről a francia törvénykönyvről magyar fordítás is készült 1867-ben Sopronban az alábbi címlappal: „A törvényjavaslat bemutatásakor az 1810. évi franczia törvényhozótest üléseiben kifejtett miniszteri elöterjesztvényekkel, és a törvényen egész a legújabb időkig tett változtatásokkal együtt. A hivatalos szöveggel egyeztetett kiadások nyomán fordította: Németh Antal, T. Sopron megye szolgabírája. Sopron, 1867.”

\section{A BELGA KIHÁGÁSI JOG 1867-ES SZABÁLYOZÁSA}

Az 1867-es belga büntető törvénykönyv az első olyan kódex Belgiumban, amely egy napóleoni törvénykönyv helyébe lépett. Az 1867-es belga Btk. előkészítő munkálatai már 1848ban elkezdődtek, miután egy királyi rendelet bizottságot hozott létre az 1810-es francia Code Pénal revíziójáról. A bizottság munkájában meghatározó szerepet játszott JacquesJoseph Haus (1796-1881), a genti egyetem professzora, aki kezdetben az 1832-1836 között publikált büntetőjogi tárgyú munkáira támaszkodott. A törvénykönyv tervezetének első részét $A$ büncselekmények és a büntettek általában (Des infractions et de la répression en général) címmel már 1853-ban elfogadta a belga Képviselőház (Chambre des représentants), nem lépett azonban hatályba, mert az akkori tervek szerint ezt csak a második, különös rész elkészülte után tervezték. A különös részi tervezetet azonban csak 1858-ban terjesztették a törvényhozás alsóháza elé, majd hosszan tárgyalták. A parlamenti viták során a már korábban elfogadott általános rész egyes rendelkezéseit is módosították. ${ }^{20} \mathrm{~A}$ belga Szenátus elé 1862-ben került a képviselőház által elfogadott szöveg, a viták azonban csak 1866-ban kezdődtek el. Az eljárás végén a Szenátus a Képviselőháznak egyszer visszaküldve végül 1867. május 17-én szavazta meg a belga Btk. szövegét. ${ }^{21}$ Az 1867-es belga Btk.

Fayer (1895) i. m. 29.

John Gilissen: Codification et projets de codifications belgique au XIXe siècle (1804-1914). Belgisch Tijdschrift voor Nieuwste Geschiedenis, 14. (1983), 1-2. 243-245.

21 Jérôme de Brouwer: Jacques-Joseph Haus et l'esprit de la réforme du Code pénal de 1810. Journal des Tribunaux, (2000). 646-650. 649-650. 
tehát elsősorban Haus professzor munkásságának eredménye, s továbbra is francia hatásokat tükröző törvénykönyv maradt. ${ }^{22}$

A belga Btk. Általános része azt a cselekményt tekinti kihágásnak, amelynél rendőrségi büntetést szabnak ki (art. 5.). Ezek a büntetések a következők voltak: pénzbüntetés (1-25 frank); elzárás (általában 1-7 napig); kivételes esetben speciális lefoglalások. A belga Btk. 2. fejezetének X. címe tárgyalja a kihágások egyes nemeit. A belga 1867-es Btk. francia hatásra a kihágásokat szintén osztályokba sorolta.

$\mathrm{Az}$ 1. osztályba tartoztak az 1-10 frank pénzbüntetéssel büntethető cselekmények (art. 551-554.), mint például a tűzrendvédelmi szabályokba ütköző, az utak tisztításának, karbantartásának elmulasztásával kapcsolatos és a közterületek kivilágításának elmaradása miatti esetek.

A 2. osztályba a 5-15 frank pénzbüntetés kiszabását eredményező cselekmények tartoztak (art. 555-558.), mint például a vendéglősök, fogadósok bejelentési, nyilvántartási kötelezettségének elmulasztásával, épületek elhanyagolásával, állatok elhagyásával, a segítségnyújtás elmulasztásával, a hazárdjátékokkal, a károsító anyagok elhagyásával és a terméklopással kapcsolatos esetek.

A 3. osztály a 10-20 frank pénzbüntetéssel sújtható cselekmények (art. 559-562.) kategóriája volt. Idetartoztak például a más tulajdonában való károkozás enyhébb esetei, a kidobott vagy veszélyes anyagok miatti károkozás, a fegyverrel okozott károk, a leomlással fenyegető épület, a más által legálisan elhelyezett plakátok letépése, az éjszakai csendháborítás, ételek, italok hamisítása, súlyok, mértékek meghamisítása, állatokkal való kegyetlen bánásmód, állatviadalok szervezése, rágalmazás és a rosszindulatú hírbe hozás.

A 4. osztály a legsúlyosabban minősülő kihágásokat magában foglalva már 15-25 frank pénzbüntetést és 1-7 napig történő elzárást is eredményezhetett (art. 563-564). Idetartozott többek között a jósdák üzemeltetése, a városi, vidéki elválasztó falak megrongálása, a rágalmazással nem járó személysértések esetei, a kővel való megdobás és a telefon-, telegráfvezetékek gondatlan megrongálása.

A belga Btk.-ban az egyes kihágások típusai mellett közös rendelkezések voltak a viszszaesőkre, enyhítő körülmények esetén való büntetésmérséklésre és a büntetések végrehajtására.

A Haus professzor irányításával 17 évnyi parlamenti vita után elfogadott 1867-es Btk.-ban található belga kihágások szabályozása erősen magán viselte a napóleoni 1810-es francia törvénykönyv hatásait. Ez abban is megmutatkozott, hogy a szankciók kiszabására a kifejezetten a kihágások elbírálására felállított bíróságok, az első fokon eljáró Rendőri Kihágási Bíróságok (Tribunal de police) voltak jogosultak.

22 Fred Stevens: La codification pénale en Belgique, héritage français et débats néerlandais (1781-1867). In René Lévy - Xavier Rousseaux (dir.): Le pénal dans tous ses États: Justice, États et sociétés en Europe (XIIe-XXe siècles). Bruxelles, Presses de l'Université Saint-Louis, 1997. 298-302. 


\section{AZ 1871. ÉVI NÉMET BTK. SZABÁLYAI A KIHÁGÁSOKRÓL}

Közismert, hogy a német büntetőjog kialakulására a római jog is jelentős hatást gyakorolt, különösen a libri terribilesnek nevezett Digesta 47-48. könyvei. ${ }^{23} \mathrm{Az}$ első német Btk. (RStGB) föként az 1851-es porosz büntetö törvénykönyv (Preussisches Srafgesetzbuch) és a francia Code pénal hatására jött létre 1871-ben (Reichsstrafgesetzbuch). ${ }^{24} \mathrm{Az} 1871$. május 15-én elfogadott és 1872 . január 1-jén hatályba lépő törvény egyik célja a német birodalmi jogegység megteremtése volt. ${ }^{25}$ Elsősorban a különös rész rendkívüli precizitással megalkotott tényállásai voltak jelentős hatással a Csemegi-kódex összeállítóira. ${ }^{26}$

A német törvénykönyv a büncselekmények tekintetében a klasszikus hármas felosztást tartalmazta büntett (Verbrechen), vétség (Vergehen) és kihágás (Übertretungen, Ordnungswidrigkeit) között különbséget téve. ${ }^{27} \mathrm{~A}$ kihágásokat a törvénykönyv utolsó része 360-370. $\$$ tartalmazta. ${ }^{28} \mathrm{~A}$ német törvénykönyv a szankciók tekintetében a hegeli és a kanti filozófia jegyében a generálprevenció elvét követte, így kihágások tekintetében két szankciót irányzott elő: a pénzbüntetést (Geldstrafe) és a fogva tartást (Haft).

A német RStGB a kiróható büntetés súlyossága szerint osztályozta a kihágásokat. A két büntetésnem figyelembevételével és kombinációjával az alábbi kihágási osztályokat hozta létre: az ötven tallérig, vagy fogva tartással büntethetők (360. § és 370 . \$); fogva tartással büntethetők (361. \$); a 20 tallérig és 14 napi fogva tartással büntethetők (366. $\$ 368$. \$); a 30 tallérig vagy négy hét fogva tartással büntethetők (369. \$).

A német kihágási eljárás bírósági eljárás, amelynek során az általános hatáskörrel eljáró illetékes közigazgatási bíróság (Amtsgericht) állapította meg a bűnösséget és az esetleges szankciót.

Tehát a német kihágási jogot a 19. századi modelleknek megfelelően a többi bűncselekménytípussal együtt egységes törvénykönyvben szabályozták - a francia és belga kódexek mintájára a szankciók súlya szerinti csoportokba osztva.

\section{5. ÖSSZEFOGLALÁS}

Rövid tanulmányom összefoglalásaként határozottan megállapítható, hogy a Csemegi által kodifikált magyar büntetőjog szakított a büncselekmények hármas felosztásának egy

23 Fayer (1895) i. m. 23

24 Wolfgang Sellert: Strafrecht und Strafrechtskodifikation im 18. und 19. Jahrhundert in Deutschland. In Mezey Barna (szerk.): Rechtsgeschichtliche Abhandlungen Band 21. Strafrechtskodifikation im 18. und 19. Jahrhundert. Budapest, Mezey Barna, 1997. 131-139. 139.

25 Thomas Vorbaum: Einführung in die moderne Srafrechtsgescichte. Heidelberg, Springer, 2011. 85-88.

26 Rigó (2016) i. m. 350-351.

27 Stipta István: A német és osztrák állam és jog fejlődése a porosz-osztrák háborút (1866) követő időszakban. In Horváth Pál (szerk.): Általános jogtörténet. Budapest, Tankönyvkiadó, 1991. 451.

28 Wolfgang Mitsch: Geschichte des Ordnungswidrigkeitenrechts. In Recht der Ordnungswidrigkeiten. BerlinHeidelberg, Springer Verlag, 2005. 23-28. 23-24. 
törvénykönyvbe való elhelyezésével (francia, belga, német modell). Nem követi a francia és belga modellt, amely a büncselekménytípusnak megfelelő egységes bíróságot hozott létre, hanem a kihágások elbírálását részben a járásbíróságok, részben a közigazgatási hatóságok hatáskörébe utalta. Nem követte a francia és belga modellt a kihágások büntetési tételei szerinti osztályokba sorolásnál sem. A magyar Kbtk. ugyan figyelembe vette az európai mintákat, de egyiket sem követte szolgai módon. A magyar törvény föként az osztrák Btk. osztályozását tekintette modellnek. A kihágások anyagi jogát európai színvonalon szabályozta ugyan, de az eljárások hatékony lefolytatásához szükséges szervezeti változtatások nem történtek meg, így nem jött létre a francia és a belga mintának megfelelően működő egységes és általános kihágási bíróság, ezáltal az eljárások anyagi és személyi feltételei sem lettek kielégítően biztosítva. Ez vezetett oda, hogy a magyar közigazgatási hatóságok által hozott ítéletekkel szemben a Kormányhoz is lehetett fellebbezni, ami azt eredményezte, hogy a kormánytagok a fontos állami döntések mellett bagatell jellegü kihágási ügyekkel is kénytelenek voltak foglalkozni üléseiken. Ez - mind a fentiekben láttuk - a francia, belga és német törvénykönyvek alapján nem volt lehetséges. 


\section{FELHASZNÁLT IRODALOM}

1. Cabanis, André: Target Guy-Jean-Baptiste. In Patrick Arabeyre - Jean-Louis Halpérin - Jacques Krynen (sous la direction): Dictionnaire historique des juristes français XIIe - XXe siècle. Paris, PUF, 2007. 955-956.

2. Carbasse, Jean-Marie: Introduction historique au droit pénal. Paris, PUF, 1990.

3. Brouwer, Jérôme de: Jacques-Joseph Haus et l'esprit de la réforme du Code pénal de 1810. Journal des Tribunaux, (2000), 646-650.

4. Fayer László: A büntetöjog kézikönyve I. Budapest, Franklin Társulat, 1895.

5. Gilissen, John: Codification et projets de codifications belgique au XIX ${ }^{e}$ siècle (18041914). Belgisch Tijdschrift voor Nieuwste Geschiedenis, 14. (1983), 1-2. 203-285.

6. Hajdú Lajos: Az államszervezet és jog fejlődése Itáliában. In Horváth Pál (szerk.): Általános jogtörténet. Budapest, Tankönyvkiadó, 1991. 455-466.

7. Illés Károly: A kihágásokról szóló magyar törvények és az azokra vonatkozó eljárási szabályok magyarázata. Budapest, Singer és Wolfner Kiadása, 1892.

8. Kajtár, István: Strafrechtsrezeption in Ungarn in dem 19. Jahrhundert. In Mezey, Barna (szerk.): Strafrechtsgeschichte an der Grenze des nächtsten Jahrtausendes. Budapest, Gondolat, 2003. 27-53.

9. Lacchè, Luigi: Un code pénal pour l'Unité italienne, le code Zanardelli (1889): la genèse, le débat, le projet juridique. In Le pénal dans tous ses États: Justice, États et sociétés en Europe (XII-XXe siècles). Bruxelles, Presses de l'Université Saint-Louis, 1997. 303-319. DOI: https://doi.org/10.4000/books.pusl.19152

10. Laingui, André - Arlette Lebigre: Histoire du droit pénal I. Paris, Cujas, 1979.

11. Lepointe, Gabriel: Histoire des institutions du droit public français au XIX ${ }^{e}$ siècle (17891914). Paris, Montchrestien, 1992.

12. Lenoël, Pierre: Treilhard Jean-Baptiste. In Patrick Arabeyre - Jean-Louis Halpérin - Jacques Krynen (sous la direction): Dictionnaire historique des juristes français XII $-X^{e} X^{e}$ siècle. Paris, PUF, 2007. 977-978.

13. Mezey Barna: Egy jogászkarrier a 19. században. Csemegi Károly (1826-1899). In A praxistól a kodifikációig. Csemegi Károly emlékére, 1826-1899. Budapest, Osiris, 2001. 9-23.

14. Mezey, Barna: Strafrechtskodifikation in Ungarn im Jahre 1878. In Mezey, Barna (szerk.): Strafrechtsgeschichte an der Grenze des nächtsten Jahrtausendes. Budapest, Gondolat, 2003. 151-177.

15. Mitsch, Wolfgang: Geschichte des Ordnungswidrigkeitenrechts. In Recht der Ordnungswidrigkeiten. Berlin-Heidelberg, Springer, 2005. 23-28.

16. Oppetit, Bruno: Essai sur la codification. Paris, PUF, 1998. DOI: https://doi.org/10.3917/ puf.oppet.1998.01

17. Rigó Balázs: A büntetőjog történetéből II. Kora újkor - újkor. In Földi András (szerk.): Összehasonlító jogtörténet. Budapest, ELTE Eötvös, 2016. 325-354.

18. Sebestyén István: Csemegi Károly. In Hamza Gábor - Siklósi Iván (szerk.): Magyar jogtudósok 3. Budapest, Nemzeti Tankönyvkiadó, 2006. 43-44. 
19. Sellert, Wolfgang: Strafrecht und Strafrechtskodifikation im 18. und 19. Jahrhundert in Deutschland. In Mezey Barna (szerk.): Rechtsgeschichtliche Abhandlungen Band 21. Strafrechtskodifikation im 18. und 19. Jahrhundert. Budapest, Mezey Barna, 1997. 131-139.

20. Stevens, Fred: La codification pénale en Belgique, héritage français et débats néerlandais (1781-1867). In René Lévy - Xavier Rousseaux (dir.): Le pénal dans tous ses États: Justice, États et sociétés en Europe (XII $-X X^{e}$ siècles). Bruxelles, Presses de l'Université Saint-Louis, 1997. 287-302. DOI: https://doi.org/10.4000/books.pusl.19149

21. Stipta István: A német és osztrák állam és jog fejlődése a porosz-osztrák háborút (1866) követő időszakban. In Horváth Pál (szerk.): Általános jogtörténet. Budapest, Tankönyvkiadó, 1991. 443-454.

22. Szramkiewicz, Romuald - Jacques Bouineau: Histoire des institutions 1750-1914. Droit et société en France de la fin de l'Ancien régime à la Première Guerre mondiale. Paris, Litec, 1989.

23. Vorbaum, Thomas: Einführung in die moderne Srafrechtsgescichte. Heidelberg, Springer, 2011. DOI: https://doi.org/10.1007/978-3-642-16788-1

Jogi forrás

1. 1879. évi XL. törvénycikk a magyar büntető törvénykönyv a kihágásokról 
Prof. Dr. Pókecz Kovács Attila az NKE ÁNTK Állam- és Jogtörténeti Tanszékének és a KRE ÁJK Polgári Jogi és Római Jogi Tanszékének egyetemi tanára. Állam- és jogtudományi végzettséggel rendelkezik. Jogi tanulmányait Pécsett, Párizsban (Paris II) és Toulouse-ban végezte. Párizsban 1996-ban összehasonlító jogi diplomát, valamint jogtörténeti DEA-fokozatot szerzett. A Pécsi Tudományegyetem Állam- és Jogtudományi Karán 2006-ban szerezte PhD-fokozatát, majd ugyanitt habilitált 2013-ban. Több félévet oktatott külföldi, elsősorban francia egyetemeken. Így vendégprofesszora volt a Paris I, a Paris V, a Paris X egyetemeknek, a Bordeaux IV, valamint a tours-i és a nantes-i egyetem jogi karának. Az NKE államtudományi képzésben az Egyetemes államtörténet tantárgyfelelöse és elöadója. Kutatási területei közé tartozik az ókori római közjog, a francia közigazgatási jog története, a római magánjog, a jogi oktatás története és a borjog. Tudományos művei francia, német, angol és magyar nyelven jelennek meg. 